\title{
The Role of Internal Audit Function on Corporate Governance and Management
}

\author{
Georgios Kontogeorgis \\ Department of Public Administration \\ Panteion University of Social and Political Sciences \\ 136 Syggrou Avenue, Athens 17671, Greece \\ E-mail: giorgos.kontogeorgis@gmail.com
}

Received: September 10, 2018 Accepted: October 20, 2018 Published: October 28, 2018

doi:10.5296/ijafr.v8i4.13626

URL: https://doi.org/10.5296/ijafr.v8i4.13626

\begin{abstract}
The purpose of the paper is to examine the research question about the role of internal audit function on management and corporate governance. This paper is updated with the latest theories regarding the role of internal auditing on management and corporate governance. It has been made literature review so as to be revealed the role of internal audit function on management and corporate governance. It is found that internal auditing is an important part of the success of corporate governance. Especially, it is one of the pillars of corporate governance. Furthermore, it is found that internal audit function is a vital tool for the management and for the success of a company. The good operation of internal audit function can be a tool for the improvement of quality of the corporate governance and management. Both corporate governance and management can increase the competiveness of a company.
\end{abstract}

Keywords: Internal auditing, corporate governance, management

\section{Introduction}

In last years, a growing industry has developed around the need and desire for improved corporate governance: accounting firms offer corporate governance compliance services, business schools offer corporate governance courses and there is a growing public interest in relation with corporate governance matters (Stein, 2008). Good corporate governance is now considered a basic criterion to accept a business in the majority of the Stock Exchange Markets in the world (Al-Baidhani, 2016). Internal auditing is considered a part of corporate governance. The majority of the corporate governance codes have contexts about the 
operation of internal auditing. Internal and external auditors reduce the business risk of a company and ensure that its financial statements fairly depict the economic stability of a business (Moizer, 2005; Nerantzidis, 2015). International guidelines suggest that effective implementation of corporate governance and internal auditing improves business's performance and it is a tool for the achievement of competitive advantage (Karagiorgos et al., 2010). The failure of the Enron Corporation in the end of 2001 has as a result the raise of questions about the effectiveness of contemporary accounting, auditing and corporate governance practices (Vinten, 2002).

This paper has the following objectives:

- To clarify the definition of corporate governance and to describe the importance of it for the success of a company. Special emphasis put on the explanation of the role of corporate governance code for a business.

- To clarify the meaning of internal auditing and to highlight the role of the internal auditing in the contemporary business world.

- To explain the relationship between internal audit function and corporate governance.

- To explain the relationship between internal audit function and management.

- To clarify the research methods of the paper.

- To present the conclusions of all the above and the limitations of the study.

\section{Literature Review}

\subsection{Theoretical Background of Corporate Governance and Management}

President George W. Bush talked about the importance of the corporate governance with the following words "Through stricter accounting standards and tougher disclosure requirement, U.S.A. must be made accountable to employees and shareholders" (Bush, 2002; Rezaee et al., 2003). A web search disclosures a considerable number of different definitions of corporate governance. This justifies the existence of a myth for a consensus on the meaning of "corporate governance" (Brickley and Zimmerman, 2010; Nerantzidis and Filos, 2014). The main driver for corporate governance is based on the agency concept. Corporate bodies are overseen by directors who are appointed by the owners (Pickett, 2005).

But what is really corporate governance meaning? The use of the term "corporate governance" intensified during the economic and social changes happened for a series of countries around the middle of 1980s (Hullier, 2014). When we define corporate governance we should take into account six factors: Institutional, shareholder, governance, control, performance and stakeholders (Nerantzidis et al., 2012). Corporate governance deals with how suppliers and shareholders will ensure the return of their money (Shleifer and Vishny, 1997). Corporate governance is the link between managers, directors, labors, shareholders, clients, creditors and suppliers (Kaplan and Norton, 1996). The Organization for Economic Stability and Development (OECD) defines corporate governance as a set of relationships 
between a company's management, its board, its shareholders and other stakeholders (Mihret and Grant, 2017).

According to theorists who have specialization in agency theory, corporate governance is a systemic provision of some measure of control over the actions of agents such as managers. Indeed, agency theorists played a crucial role in developing the policy framework that supported the public sector reforms, especially the corporatization and privatization programs (Boston et al., 1996; L'Huillier, 2014). The most widely used definition of corporate governance is "the system by which companies are directed and controlled" (Cadbury Report, 1992; OECD, 1999). Milton Friedman (1962) suggested that corporate governance is to carry out the business in accordance with owners and shareholder's ambitions (Pandya/Vyas, 2013). La Porta et al. (2000) define corporate governance "as a set of mechanisms through which outside investors protect themselves against expropriation by the insiders i.e. both managers and controlling shareholders".

Holmstrom and Kaplan (2001) believe that corporate governance is "the mechanisms by which corporations and their managers are managed". It was given some definitions of corporate governance but why corporate governance is so important? Cattrysse (2005) believes that the quality of corporate governance will have a direct impact on the:

- Efficiency of corporate assets use: If a company has efficient use of corporate assets, then it will attract the investor's confidence.

- Ability to attract low-cost capital: More and more investors are evaluating corporate governance when buying stocks or other financial products and an increasing number of listed companies feel the pressure to take measures in order to adopt effective corporate governance practice. Investors usually use their exit options if they don't agree with the management or if they are disappointed by the company's performance, signaling - through share prices reduction - the necessity for managers to improve firm's performance (Hirschman, 1970; Spanos, 2005). As a result of the increase in demand for corporate governance evaluations, some specialized businesses and academic foundations offer corporate governance rating services (Spanos, 2005).

- Ability to meet social expectations. Profitable businesses can help a society to have progress and national prosperity.

- Overall performance. Corporate governance improve all the departments of a company and so it can be achieved a whole improvement of the performance of a business.

Lastly, corporate governance has significant implications for the growth prospects of an economy. Proper corporate governance practices reduce risk for investors, attract investment capital and improve corporate results (Spanos, 2005).

\subsection{Corporate Governance Codes}

Corporate governance principles and guidelines are adopted by many businesses or nonprofit organizations to provide best practices of the corporate governance (Rezaee et al., 2003). The corporate governance codes were developed using both international best practices and 


\section{Ml Macrothink}

International Journal of Accounting and Financial Reporting

ISSN 2162-3082

2018, Vol. 8, No. 4

national corporate governance principles. For example, the Kuwaiti code (Capital Standards Rating Agency, 2010; Shehata, 2015) mentions in its references that "corporate governance code includes principles and recommendations which are primarily based on international best practices and the corporate governance principles issued by the OECD". The first code of good governance issued in the USA in the end of 1970s, with business, legal, academic, and political constituencies discussing about what the role of the board of directors should be (Aguilera and Cuervo-Cazurra, 2004). The main target for each corporate governance code is to offer a guideline for the board on how to govern a company. Another purpose is to inform both shareholders and stakeholders about the enterprise's issues. Finally, a corporate governance code offers a set of rules, which each company disclosures its implementation. This is very useful for the stakeholders because of the fact that they can make comparisons using quantitative and qualitative tools about the evaluation of the corporate governance. If the governance mechanisms are not disclosure, the firm's stakeholders may not be able to have access to calculate the quality corporate governance (Darmadi, 2013).

A corporate governance statement is a summary of the processes by which a company is controlled. The corporate governance statement is a very useful statement, which provides information about the quality of corporate governance for a company. The following are some information that corporate governance statement provides:

- It mentions which corporate governance code is implemented by a company.

- It gives details about the operation of the General Assembly. It describes the obligations and the rights of shareholders.

- It states what best practices implement a company without being obligated by the law.

- It describes the process of internal control and risk management, which a company implements for the purpose of protection of investors.

- It describes relationships with shareholders.

- It gives information about the composition of the board and the other committees of the company. It disclosures the number of the executive and the no executive members of the board.

- It gives information about the remuneration of the members of the board.

- It gives explanations about the deviations of the corporate governance code. Enterprises must explain any deviations of the corporate governance code.

- It gives information about the rules about the appointment of the members of the board and the procedures for their replacement.

- It reveals information about the rights which have the minority shareholders and how they are protected.

- It gives information about the shares which may a company has to other businesses. 


\subsection{Theoretical Background of Internal Auditing}

Based on documents that have been found, historians have concluded that around 3000 B.C., Mesopotamian people utilized systems of internal controls such as ticks and checks. Auditing has evolved over the pass of the years and today we generally detect of two kinds of business auditors: external and internal (Moeller, 2009). It is a good idea to start with the Lawrence Sawyer, known as the father of internal audit, to open the discussion about the audit role. Sawyer has said that audit has a long and brilliant history which dates back from Ancient Rome (Pickett, 2005).

Many definitions have been written in connection with the concept of internal control and internal audit. According to COSO (1992), "Internal control is defined as a process effected by an entity's board of directors, management and other personnel, designed to provide reasonable assurance regarding the achievement of objectives in the following three categories: Effectiveness and efficiency of operations, reliability of financial reports and compliance with applicable laws and regulations". Pickett (2005) stated that controls are classified as follows:

- Directive: to ensure that there is a clear orientation on achieving the targets of an organization.

- Preventive: to ensure that systems work in the first place.

- Detective: to pick up transaction errors those have not been prevented.

- Corrective: to ensure that the identified problems have been resolved.

According to the Institute of Internal Auditors (IIA) (2004) "Internal auditing is an independent, objective assurance and consulting activity designed to add value and improve an organization's operations. It helps an organization accomplish its objectives by bringing a systematic, disciplined approach to evaluate and improve the effectiveness of risk management, control and governance processes". Sawyer (2003) stated that internal auditing is "a systematic, objective appraisal by internal auditors of the diverse operations and controls within an organization to determine whether (1) financial and operating information is accurate and reliable, (2) risks to the enterprise are identified and minimized, (3) external regulations and acceptable internal policies and procedures are followed, (4) satisfactory operating criteria are met, (5) resources are used efficiently and economically and (6) the organization's objectives are effectively achieved - all for the purpose of consulting with management and for assisting members of the organization in the effective discharge of their governance responsibilities".

The Institute of Internal Auditors (IIA) issues the International Professional Practices Framework (IPPF). The professional practice framework contains the basic principles of conducting profession. The IPPF consists of three sets of standards, all of which are mandatory: A. Attribute standards, B. Performance Standards and C. Advisories Guidelines (Kontogeorgis and Filos, 2012). 
The current version of the standards consists of what are called attribute standards, performance standards, and implementation standards. The attribute standards include information about the activities and special areas of a business. The performance standards describe the internal audit activities and provide criteria for the evaluation of audit process (Moeller, 2009). The standards are designed to provide the basic principles for the implementation of internal audit and help to improve the processes and functions within a company (Kontogeorgis and Filos, 2012).

\subsection{The Role of Internal Audit Function on Corporate Governance and Management}

Internal audit function is responsible for the operation of internal audit within a company. The pillars for the good operation of internal audit function are resources, competence of auditors, structure and the implementation of IIA'S International Standards (Institute of Internal Auditors, 2017).

The regulation compliance has also increased in relation with capital market regulation over the recent years, mainly due to globalization of the need of financial accounting and integrated reporting (Velte, 2014). In looking to explain the development of auditing, Power identifies a number of important factors including a growth of interest in corporate governance and organizational role for internal control systems (Humphrey and Owen, 2000). The most widely known definition of internal auditing and the standards has drawn up and implemented by the IIA and it gives the internal auditor the obligation to contribute in a variety of ways to the evaluation of the corporate governance process (Cattrysse, 2005). Internal audit helps compliance within the corporate governance framework in two ways. Firstly, internal audit is an integral component of the business monitoring system. Secondly, its fieldwork results help a company to keep up with compliance requirements. Internal audit is involved in the overall corporate governance practice in a variety of ways (Kagermann et al., 2008). Here are some examples of the role of internal auditing on corporate governance:

- Ensuring compliance with a corporate governance code (e.g., compliance with a national or international corporate governance code).

- It operates as an audit body of the board. Consequently, internal auditing helps corporate governance by reviewing the organization's practice. Consequently, it helps a company to evaluate if values of a business are communicated to employees (Karagiorgos et al., 2010).

The role of internal auditors, the last few years, has been broadened from one focused almost exclusively on the external financial reporting matters, to one concerned with general corporate governance matters (Porter, 2009).

The development of corporate accountability during the past three decades has as a result the fundamental changes in the audit function. Specifically, it has as consequence the recognition of the need of implementation for an effective and fully "audit trinity", comprising: internal auditors, external auditors, an audit committee (Porter, 2009). The Blue Ribbon Committee (1999) presents audit committees, internal auditing and external auditing as the "three-legged-s tool" of corporate governance that improves the validity of financial reports (Mihret and Grant, 2017). Internal auditing is regarded as a corporate governance mechanism 


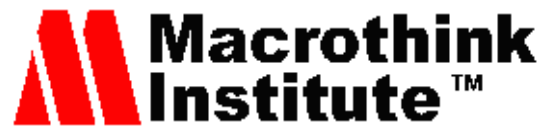

International Journal of Accounting and Financial Reporting

ISSN 2162-3082

2018, Vol. 8, No. 4

(Mihret and Grant, 2017). The basic contribution of internal auditing on corporate governance provides via the audit committee. As part of corporate governance mechanism, the audit committee overseas the organization management, internal and external auditors with main purpose to promote and preserve the shareholder's equity and interests (Al-Baidhani, 2016). The audit committee is empowered to function, on behalf of the board of directors, by assuming an important oversight role in the corporate governance with the intention of protection of the investors and the safeguard of corporate accountability (Rezaee et al., 2013). The audit committee receives reports about the internal control's effectiveness and efficiency from the organization's management, internal and external auditors (Report of the National Commission on Fraudulent Financial Reporting, 1987). Evaluation of the internal control structure and process is considered one of the most, for many people the most, important oversight responsibility of faced by the audit committee (Al-Baidhani, 2016). The success of audit committees in fulfilling their oversight responsibility is in relation with their working relationships with other players of corporate governance such as the board of directors, management, external auditors, internal auditors, legal counsels, professional institutes, standard- setting bodies (Rezaee et al., 2013).

The role of audit committee and auditors in current situation become very crucial. Stakeholders expect competence and trust from auditor and auditing committee in the operation of an organization (Pandya/Vyas, 2013). The audit committee plays a major role in corporate governance regarding the organization's direction, control and accountability. It plays also an important role regarding the organization's internal control to provide reasonable assurance about the ethical values of management and reliability of financial information (Al-Baidhani, 2016). If a company has a good structured audit committee then independent auditors' working will be supported. Moreover, the system of selection and appointment of auditor are crucial matters for the quality of audit (Pandya/Vyas, 2013). It is now generally agreed that internal auditing and corporate governance affects all kinds of economic operation of a business (Karagiorgos et al., 2010). The required skills of audit committee's members have been increased because audit committees involve not only with corporate governance but with other customer relationship matters also (Porter, 2009). The last years, it has been grown the meaning of continuous auditing. The meaning of continuous auditing, among others, is related with an immediate action after the occurrence of an event (Lins et al., 2016). This fact highlights the role of internal auditing.

The statutory responsibilities (Pandya/Vyas, 2013) of the auditor fundamentally require the following:

- Duty to provide information to management.

- Duty to make a report to the company about the problems.

- Duty to follow the corporate policy.

- Detection and prevention of illegal practices.

- Duty to report illegal acts. 
- Duty to act with competence.

There are some main indicators in relation with the level of work that is required by the auditor (F.E.E., 2009; Nerantzidis, 2015):

- The level of disclosure of corporate governance statement. The corporate governance statement can be presented in the annual report or issued separately.

- The requirements which have been imposed by the Member State law. Some countries requires more than European Union requirements about the corporate governance disclosure.

Internal controls are "systematic measures (such as reviews, checks and balances, methods and procedures) instituted by an organization to (1) conduct its business in an orderly and efficient manner, (2) safeguard its assets and resources, (3) deter and detect errors, fraud, and theft, (4) ensure accuracy and completeness of its accounting data, (5) produce reliable and timely financial and management information, and (6) ensure adherence to its policies and plans" (Businessdictionary, 2017).

This definition recognizes that internal control includes all enterprise issues and not just accounting and financial matters (Moeller, 2009). The role of internal auditors has been broadened during the past couple of decades to combine general corporate governance with accountability matters (Porter, 2009). The disclosures of internal audit information and information about the composition of board monitoring play an important role in reducing the impact of agency cost and the lack of information that may face the stakeholders of a company (Agyei-Mensah, 2016).

Whenever a company collapsed unexpectedly, there is always a suspicion that the internal control system was ineffective and bad organized. It appears to have ineffective risk management policy (Agyei-Mensah, 2016). Auditor has the obligation to detect wrongdoer and to report it. An independent auditor can play his role effectively (Pandya/Vyas, 2013). Much more duties are placed on auditors in the perspective of corporate governance because auditor is very likely the first person to detect corporate weakness (Pandya/Vyas, 2013). Strong investor protection may be a particularly important sign of security against political interference in some countries.

The definition of internal auditing states that internal auditing offers services such as assurances. The meaning of this is that internal audit function offers advisory services to managements so as to achieve the business' objectives (Bou-Raad, G., 2000). Internal audit function supports management with two ways. The first is to detect the productive or no productive areas of a company and the second is to inspect the financial areas of a company (Pinto et. al., 2014). Internal audit function makes reviews and recommendations so as to add value for the entity. Moreover, internal audit activity has as a result on the achievement of operational business's goals (Koutoupis and Pappa, 2018) and the on the increase of the level of validity of financial reporting (Gamayuni, 2018).

The effectiveness of the board and senior management can be enhanced according to Cattrysse (2005) by: 


\section{Al Macrothink}

International Journal of Accounting and Financial Reporting

- Recognizing the importance of the audit process.

- Taking measures that improve the operation and power of auditors.

- Utilizing, in a quick and effective manner, the work of auditors.

- Ensuring the independence of the Chief Audit Executive.

Furthermore, Porter (2009) considers that internal auditors frequently have responsibility for:

- The business' internal audit function.

- Identifying that all risks faced by the entity are identified in a quick and effective way.

- Making and controlling the company's policy.

- Preventing illegal acts.

- Making environmental audits.

Internal Audit Guidance for Financial Services (CIAGFS, 2013; Chambers and Odar, 2015) considers that the following should be in the responsibility of internal audit:

- Internal governance mechanisms.

- Information presented to the board and management so as to take the right decisions.

- Risks of poor customer service,

- Risks such as capital and liquidity.

- Results of processes.

Moreover, Pinto et. al. (2014) state that internal audit function should play some extra roles for a company. These roles are:

- It helps management to identify threats and opportunities so as to improve its results. It helps the decision making for the management of a company.

- It minimizes the potential risk which may face a company.

- It increases the social responsibility of a company and it has a result the image of the company to be improved.

- It improves the effectiveness and efficiency of the company performance.

All the above show that internal auditing is important part corporate governance and it is a vital tool for the management of a company.

\section{Research Method}

The main target of the paper is to put light on the role of internal audit function on both corporate governance and management. The above target is achieved by an extensive bibliographic review about the role of internal audit function on corporate governance and management. The selection of bibliographic review as research method services some 
purposes. It helps to present the previous researches, to put light on differences among studies, to draw conclusions and to explain the historical evolution of the topic (Hart, 1998).

\section{Conclusions}

Many definitions have been written about the meaning of corporate governance and internal auditing. The first signs of corporate governance and internal auditing date back many years ago. A widely known definition about corporate governance is "the way which companies are controlled". Many definitions about the internal audit recognize the internal auditing includes all enterprise processes which affect direct or indirect the future of a company.

The corporate governance statement is the result of the applied corporate governance policy. A corporate governance statement is a summary of the processes by which a company is controlled. It is common practice a corporate governance statement to follow a corporate governance code. Corporate governance code it is a set of norms in which enterprises are controlled. It have been developed many corporate governance codes around the world.

Internal auditing is a part of corporate governance and as a part affects the quality of corporate governance and so the quality of corporate governance statement. Internal auditors evaluate the effectiveness of the corporate governance of a company. Thus, the internal auditor becomes 'a crucial part' of the corporate governance procedure. They ensure the implementation of the corporate governance code. Audit committee is an invaluable mechanism for a company because it overseas the organization's management, internal and external auditors. The audit committee issues reports about the operation of internal audit function of an organization. Audit committees are vital to investors and internal auditors.

There are limitations about the role of internal audit function on corporate governance and management. There are some problems which may internal audit function fails to solve. For instance, many times members of board have conflict of interest or insufficient training or education.

Internal audit function is a basic key for the improvement of the corporate governance for a company and for the upgrade of the quality of corporate governance and management. Good corporate governance is now considered a basic condition to accept a business in the Stock Exchange Market for a variety of countries. Stock Exchange is a source via companies can lend money and in this way they can develop their investments. Investments are necessary for a company so as to have prosperity. Internal audit function has undertaken many advisory duties within an enterprise. It has as a consequence internal audit function to be in communication with the management in the achieving of corporate goals.

\section{Limitations}

There is a question about the definition of corporate governance and there is not a common consensus about the content of it (Nerantzidis, 2015). Cattrysse (2005) suggest some factors, which have as a result the bad corporate governance:

- Board members who face conflict of interest. 


\section{Macrothink}

International Journal of Accounting and Financial Reporting

ISSN 2162-3082

2018, Vol. 8, No. 4

- Dependence of board members from the compensation fee to make their living.

- Lack of time commitment by board members to the company's targets and needs.

- Lack of meritocracy in the appointment of members of the board.

- Lack of training within an organization.

- Lack of orientation to comply with rules, laws and other regulations.

Many times internal audit function is difficult to detect all the above everyday problems within an enterprise. However, despite the benefits attached to effective corporate governance and increasing pressures to enhance it, changing governance systems is not an easy procedure because governance rules are affected by many factors of environment (Hollingsworth et al., 1994; Hollingsworth and Boyer, 1997; Whitley, 1999; Aoki, 2001; Aguilera and Cuervo-Cazurra, 2004).

For all the above arguments, nonstop working towards improving the quality of internal audit function is an important tool for the improvement of corporate governance (Cattrysse, 2005). Boards are overall responsible for their companies, but boards operate within a partial assurance vacuum. Internal audit function can fill the board's assurance vacuum to a much greater extent than at present (Chambers and Odar, 2015).

\section{References}

Aguilera, R.V., \& Cuervo-Cazurra, A. (2004). Codes of good governance worldwide: what is the Trigger?. Organizational Studies, 25(3), 415-443.

Agyei-Mensah, B. (2016). Internal control information disclosure and corporate governance: evidence from an emerging market. Corporate Governance International Journal of Business in Society, 16(1), 79-95.

Al-Baidhani, Am. (2016). The nature of a dynamic relationship between audit committee and auditors both internal and external. Business and Economics Journal, 7(4), 1-5.

Aoki, M. (2001). Towards a comparative institutional analysis. Cambridge, MA: MIT Press.

Blue Ribbon Committee. (1999). Improving the effectiveness of corporate audit committees. New York, NY: New York Stock Exchange.

Boston, J., Martin, J., Pallot, J., \& Walsh, P. (1996). Public Management: The New Zealand model. Auckland, New Zealand: Oxford University Press.

Bou-Raad, G. (2000). Internal auditors and a value - added approach: the new business regime. Managerial Auditing Journal, 15(4), 182-187.

Brickley, J. A., \& Zimmerman, J. L. (2010). Corporate governance myths: comments on Armstrong, Guay and Weber. Journal of Accounting and Economics, 50(2/3), 235-245.

Bush, G. W. (2002, January 29). The President's State of the Union Address. Retrieved September 8, 2017, from www.whitehouse.gov/news/releases/2002/01/ 20020129-11.html 
Businessdictionary

(2017).

Retrieved

September

8, 2017, from http://www.businessdictionary.com/definition/internal-control.html

Cadbury Report. (1992). Report of the Committee on the Financial Aspects of Corporate Governance. United Kingdom: Gee Professional Publishing Ltd.

Capital Standards Rating Agency (CSR). (2010). CSR Corporate Governance Code - Kuwait. Kuwait: Capital Standards Rating Agency.

Cattrysse, J. (2005). Reflections on corporate governance and the role of internal auditor. Retrieved September 10, 2017, from https://www.researchgate.net/publication/228253690_Reflections_on_Corporate_Governance _and_the_Role_of_the_Internal_Auditor

Chambers, A., \& Odar, M. (2015). A new vision for internal audit. Managerial Auditing Journal, 30(1), 34-55.

CIAGFS (Committee on Internal Audit Guidance for Financial Services). (2013). Effective internal audit in the financial services sector - Recommendations from the Committee on Internal Audit Guidance for Financial Services. London: Chartered Institute of Internal Auditors.

Committee of the Sponsoring Organizations of the Treadway Commision. (1992). Internal control integrated framework (COSO). New York, U.S.A: AICPA.

Darmadi, S. (2013). Corporate governance disclosure in the annual report: An exploratory study on Indonesian Islamic banks. Humanomics, 29(1), 4-23.

Federation of European Accountants, F.E.E. (2009). Discussion paper for auditor's role regarding providing assurance on corporate governance statements. Retrieved July 8, 2017, from

www.fee.be/images/publications/company_law/DP_Assurance_on_Corporate_Governance_S tatements_0911_Colour20112009541533.pdf

Gamayuni, R. R. (2018). The Effect of Internal Audit Function Effectiveness and Implementation of Accrual Based Government Accounting Standard on Financial Reporting Quality. Review of Integrative Business and Economics Research, 7, 46-58.

Hart, C. (1998). Doing a Literature Review: Releasing the Research Imagination. London: Sage.

Hirschman, A. (1970). Exit, Voice, and Loyalty: Responses to Decline in Firms, Organizations, and States. Cambridge, Mass: Harvard University Press.

Hollingsworth, R., \& Boyer, R. (1997). Contemporary Capitalism: The Embeddedness of Institutions. New York: Cambridge University Press.

Hollingsworth, R., Schmitter, P., \& Streeck W. (1994). Governing Capitalist Economies. Oxford: Oxford University Press. 


\section{MIMacrothink}

International Journal of Accounting and Financial Reporting

ISSN 2162-3082

2018, Vol. 8, No. 4

Holmstrom, B., \& Kaplan, S. (2001). Corporate governance and merger activity in United States. Retrieved July 8, 2017, from http://www.mc2consulting.com/govloop.htm

Hullier, B. (2014). What does corporate governance actually means?. Corporate Governance, 14(3), 300-319.

Humphrey, C., \& Owen, D. (2000). Debating the power of audit. International Journal of Auditing, 4(1), 29-50.

Institute of Internal Auditors. (2004). International Standards for the professional practice of internal auditing. Retrieved July 10, 2017, from http://www.theiia.org/?doc_id=1499

Institute of Internal Auditors. (2017). Strong Foundations: A Pulse of Internal Audit Supplemental Report.

Kagermann, H., Kinney, W., Kuting K., \& Weber, C. (2008). Internal Audit Handbook. Berlin Heidelberg: Springer-Verlag.

Kaplan, R., \& Norton, D. (1996). The Balanced Scorecard: Translating Strategy into Action. Boston: Harvard Business School Press.

Karagiorgos, T., Drogalas, G., Gotzamanis, E., \& Tampakoudis, I. (2010). Internal Auditing as an effective tool for corporate goverance. Journal of Business Management, 2(1), 15-23.

Kontogeorgis, G., \& Filos, J. (2012). The Implementation of Internal Auditing in Greece. The South European Review of Business Accounting and Finance, 10, 22-38.

Koutoupis, A. G., \& Pappa, E. (2018). Corporate governance and internal controls: a case study from Greece. Journal of Governance and Regulation, 7(2), 91-99.

L'Huillier, B. (2014). What does "corporate governance" actually mean?. Corporate Governance, 14(3), 300-319.

La Porta, R., Lopez-de-Silanes, F., Shleifer, A., \& Vishny, R.W. (2000). Investor protection and corporate governance. Journal of Financial Economics, 58(1-2), 3-27.

Lins, S., Schneider, S., \& Sunyaev, A. (2016). Trust is good, control is better: Creating secure clouds by continuous auditing. IEEE Transactions on Cloud Computing, 1-14.

Mihret, D., \& Grant, B. (2017). The role of internal auditing in corporate governance: a Foucauldian analysis. Accounting, Auditing \& Accountability Journal, 30(3), 699-719.

Moeller, R. (2009). Brink's Modern Auditing. New Jersey: John Wiley and Sons Inc.

Moizer, P. (Ed.) (2005). Governance and Auditing: Corporate Governance in the New Global Economy. Cheltenham: Edward Elgar Publishing Limited.

National Commission on Fraudulent Financial Reporting. (1987). Report of the National Commission on Fraudulent Financial Reporting. Washington: Treadway Commission. 


\section{Mll Macrothink}

International Journal of Accounting and Financial Reporting ISSN 2162-3082 2018, Vol. 8, No. 4

Nerantzidis, M. (2015). Measuring the quality of the "comply or explain" approach: Evidence of the implementation of the Greek Corporate Governance Code. Managerial Auditing Journal, 30(4/5), 373-412.

Nerantzidis, M., \& Filos, J. (2014). Recent corporate governance developments in Greece. Corporate Governance: The International Journal of Business in Society, 14(3), 281-299.

Nerantzidis, M., Filos, J., \& Lazarides, T. (2012). The puzzle of corporate governance definition(s): A content analysis. Corporate Board: Role, Duties \& Composition, 8(2), 15-23.

OECD. (1999). Principles of Corporate Governance. Paris: OECD.

Pandya/Vyas, H. (2013). Corporate Governance: Role of auditor and auditing committee. International Journal of Management, 1(2), 1-7.

Pickett, K. (2005). The Essential Handbook of Internal Auditing. New Jersey: John Wiley and Sons Ltd.

Pinto, J., Pereira, A., \& Peters, M. (2014). Role of internal audit in managerial practices in organisations. African Journal of Business Management, 8(2), 68-79.

Porter, B. (2009). The audit trinity: the key to securing corporate accountability. Managerial Auditing Journal, 24(2), 156-182.

Rezaee, Z., Olibe, K., \& Minmier, G. (2003). Improving corporate governance: the role of audit committee disclosures. Managerial Auditing Journal, 18(6/7), 530-537.

Sawyer, L. (2003). Sawyer's Internal Auditing, The practice of Modern Internal Auditing. The Institute of Internal Auditors, 5, 120-121.

Shehata, N. (2015). Development of corporate governance codes in the GCC: an overview. Corporate Governance, 15(3), 315-338.

Shleifer, A., \& Vishny, R. W. (1997). A Survey of Corporate Governance. The Journal of Finance, 52, 737-783.

Spanos, L. (2005). Corporate governance in Greece: developments and policy implications. Corporate Governance: The International Journal of Business in Society, 5(1), 15-30.

Stein, M. (2008). Beyond the boardroom: governmental perspectives on corporate governance. Accounting, Auditing \& Accountability Journal, 21(7), 1001-1025.

Velte, P. (2014). Improving Corporate Governance Quality Through Modern Controlling Integrated Reporting in the German Two Tier System. Business and Economics Journal, 5(1), $1-5$.

Vinten, G. (2002). The corporate governance lessons of Enron. Corporate Governance: The International Journal of Business in Society, 2(4), 4-9.

Whitley, R. (1999). Divergent Capitalisms: The Social Structuring and Change of Business Systems. Oxford: Oxford University Press. 


\section{Macrothink \\ International Journal of Accounting and Financial Reporting ISSN 2162-3082}

\section{Copyright Disclaimer}

Copyright for this article is retained by the author(s), with first publication rights granted to the journal.

This is an open-access article distributed under the terms and conditions of the Creative Commons Attribution license (http://creativecommons.org/licenses/by/4.0/) 